\title{
Late Style in J.M. Coetzee's Diary of a Bad Year
}

Hermann Wittenberg

\begin{abstract}
:
J.M. Coetzee's post-millennial writing has been marked by new forms of inventiveness, formal risk-taking and narrative experimentation that have blurred the boundaries between fiction, autobiography and social commentary. Using the example of the novel Diary of a Bad Year (2007), it is argued that this latter fiction is exemplary of Edward Said's idea of "late style", accounting not only for Coetzee's surprising venture into explicit political commentary, but also his narrative minimalism. The paper looks carefully at the content and style of Coetzee's novel, contrasting its descriptive technique with earlier fictions.
\end{abstract}

Key Words: J.M. Coetzee, Diary of a Bad Year, Edward Said, late style, autobiography, ageing, minimalism

Since winning the Nobel Prize for Literature in 2003, largely on the back of the success of Disgrace (1999), his widely acclaimed powerful and controversial novel of the South African transition, J.M. Coetzee's post-millennial books have taken a surprising inward turn, puzzling readers and critics with works that confound conventional ideas about fiction - going even beyond the postmodern, meta-fictional strategies that have always characterized his work. If Disgrace can be regarded as the classic novel in which Coetzee most perfectly mastered his craft with its relentlessly unfolding tragic plot of late colonial midlife crisis, the subsequent books have had much less popular resonance, partly perhaps, because more overtly than before, they are quasi-autobiographical metafictional experiments that depart markedly from the almost realist literary mode employed in Disgrace. Thus, in his Elisabeth Costello "novel” the academic lecture format dominates, with the eponymous protagonist a thinly veiled vehicle for Coetzee's animal rights ideas; she also makes an intrusive appearance in the next novel Slow Man, on the face of it a narrative of an amputee cyclist's struggle with physical disfigurement and sexual yearning. But is it in Diary of a Bad Year (2007, henceforth DBY) that narrative minimalism in Coetzee's later style becomes most apparent, a novel which is sustained by the slenderest strand of a story. Despite some expected praise from ingrained Coetzee fans, DBY was slated by many critics as a contrived pseudo-novel in which political editorializing masquerades as a story, and where characters are flat, almost hastily drawn figures that border on caricature. As Adam Mars-Jones put it in a review titled "Even Nobel winners can make mistakes", Coetzee's "modest confessional Diary of a Bad Year does him very few favours" (2007: online). Or as David Marcus asks, "is this uneven book written in earnest?", describing it as "(n) arcissistic, didactic, structurally and politically overwrought” (2009:115). Yet even its detractors admit that it 
is a strangely compelling and disturbing book that challenges our assumptions about the novel form itself, that destabilizes the genre of autobiography, and compels readers to think more carefully about the relationship between the world and fiction. DBY is an ambivalent, fragmentary and unresolved work, comprising some brilliant philosophical essays on the one hand, but also, on the other hand, embarrassing masturbatory fantasies of an old man; and it juxtaposes erudite homage to the classics with geriatric rants against declining standards of the language, and complaints against noisy children.

One way of making sense of the fragmentary and uneven nature of DBY is to read the text as an instance of late style, a concept that Edward Said explored in his last, posthumously published book. In On Late Style: Music and Literature Against the Grain (2006), Said suggests that at the end of their lives under the shadow of their own anticipated mortality, the work of great artists sometimes "acquires a new idiom, what I shall be calling a late style" (2006:6). Said reminds us of the exceptional power of "last works that reflect a special maturity, a new spirit of reconciliation and serenity often expressed in terms of a miraculous transfiguration of common reality" (2006:6), as one could find in the examples of Shakespeare's Tempest, Goethe's Faust or Verdi's Othello. But Said is here less interested in supremely harmonious late works that are a culmination of a life-time of artistic endeavour, but another strange form of "artistic lateness ... as intransigence, difficulty, and unresolved contradiction” (2006:7). Said thus explores a form of troubled lateness which involves "a nonharmonious, nonserene tension, and above all, a sort of deliberately unproductive productiveness going against..." (2006: 7 emphasis in the original). Far from expressing an aesthetic "serenity" or detachment, or persisting with his earlier reticence to be drawn into the domain of politics, the mature, post-millennial works of Coetzee are surprisingly strongly politically inflected, willing to offend, explicitly railing against the affairs of state of the time, as already indicated by DBY's sub-title "Strong Opinions". In the context of the fraught and contested South African transition, the aesthetic refusal of a mature "serenity" and the disavowal of a "new spirit of reconciliation" (2006:6) in his work would have a decidedly political implication, especially in the light of the debates around Coetzee's emigration, and his supposed critical indictment of a post-apartheid democratic South Africa, as dissected in David Attwell's analysis of the ANC's stance on Disgrace.

Coetzee's mature work, I will suggest, is an exemplary instance of Said's theory of artistic lateness, and an exploration of this concept will allow us to make sense of his writing, in particular DBY. Aesthetic lateness may also be possible framework for the analysis of Coetzee's great literary compatriots and contemporaries, Nadine Gordimer and Athol Fugard, whose recent work is similarly marked by a Saidian form of late style. In Gordimer's most recent work, the short story collection Beethoven Was OneSixteenth Black and Other Stories (2007) is marked not only by a preoccupation with

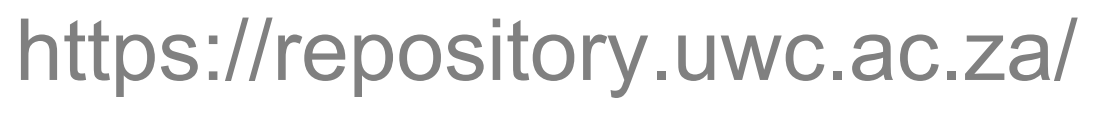


death and loss, but also displays such an uneven talent that the respected South African critic Margaret Lenta asks whether the stories are perhaps "creative exercises" and if, in respect of the "convoluted syntax and the absence of punctuation ... Penguin failed to supply an editor or whether Gordimer refused editorial services" (2007: online). If we look at Fugard's latest offering, The Train Driver (2010), the play appears at first to be a familiar set-piece of inter-racial reconciliation, but its morbid subject matter (a young woman who inexplicably chooses to kill herself and her children in front a speeding train) and setting (a makeshift graveyard), together with an ending in which the protagonist is pointlessly killed by township thugs, produce a text that is profoundly unredemptive, leaving the viewer with a sense of unresolved contradictions. With Fugard and Gordimer approaching 80 and 90 respectively, and Coetzee recently turning 70 , the great trio of South African literature may now be in its late period.

Said's theory of late style, it needs to be said however at the outset, is less a geriatric theory of literature that is concerned with reductive biographical year-counts and chronology, but rather an exploration of the way mature writers develop a different relationship towards their society, and how this shift reflects itself in the style and content of their work. Said develops his theory of lateness in a reading of Adorno's celebrated essay fragment "Spätstil Beethovens". For Adorno, Beethoven is an extreme example of a great artist who, having achieved full command over his medium, "abandons communication with the established social order of which he was part and achieves a contradictory, alienated relationship with it" (2006:8) through increasingly incomprehensible works that are no longer "vigorous and organically whole", but have become wayward, eccentric and inassimilable. The aesthetic of this form of alienated lateness is "riven with absences and silences" (2006:16), as if proclaiming that for the artist confronted with bodily decay and mortality, an overarching, grand heroic synthesis in an inconceivable illusion. For Said then, the catastrophic late style of Beethoven's final works thus constitutes "a kind of self-imposed exile from what is generally acceptable" (2006:16): their untimeliness is a furious rejection of the present, an extreme form of alienation from the very social order that had earlier celebrated his genius.

Coetzee's DBY, his thirteenth novel, might also be usefully understood as a late work, not only in the biographical sense of having been written by an author then approaching 70 (and becoming aware of his own mortality), but also as an embodiment of late style that shatters the very novel form that Coetzee, in a literary career spanning over forty years, had invested his creative and critical energies. In a perhaps self-reflective moment on the last pages of DBY, Coetzee, without using Saidian terms (DBY was written before Late Style was published, although parts of Said's book had appeared as essays before), comments on the paradoxical nature of late authorship in remarkably similar ways:

\section{https://repository.uwc.ac.za/}


Growing attachment from the world is of course the experience of many writers as they grow older, grow cooler or colder. The texture of their prose becomes thinner, their treatment of character and action more schematic. The syndrome is usually ascribed to a waning of creative power; it is no doubt connected with the attenuation of physical powers, above all the power of desire. Yet from the inside the same development may bear quite a different interpretation: as a liberation, a clearing of the mind to take on more important tasks. (2007:193)

Coetzee here makes two points about late style that he ironically here pathologises as a "syndrome": firstly, there is a stylistic simplification or reduction in the language. As will be examined more closely later, the writer appears to take short-cuts in the prose that result in an impoverishment of the former richness of description and the fulltexturedness of characterisation. Coetzee's other point relates more to content and subject matter: what are then the "more important tasks" that an aging writer must accomplish? If we consider his Elisabeth Costello novels, it is animals that matter, or more precisely how humans relate to animals. In DBY ethical questions around animals remain significant, but it is more generally concerned with the state of the world, the encroachment of state power in a post 9/11 world, and the decline of standards in taste and morals. But Coetzee also answers this question rather differently with reference to Tolstoy's late didacticism: "Far from declining, he must have felt, he was ridding himself of the shackles that had enslaved his appearances, enabling him to face directly the one question that truly engaged his soul: how to live" (2007:193). DBY, I will suggest, is similarly occupied with the final question of "how to live" when one is dying, or how, close to death, trapped in a frail, doddering body, one can recapture the "power of desire" for one last time, achieving, finally, the union of a "shrunken old man and this earthly incarnation of heavenly beauty" (2007:190). DBY therefore repudiates its own dry didacticism in favour of late love.

A closer look at the text now follows. This is the novel: a famous South African author, now living in Australia, is invited by a German publisher to contribute his views "on what is wrong with the world" to a book titled "Strong Opinions". The polemical essays on a wide range of topical political, social and moral issues form the core of the novel, and range from short paragraph-long pieces to a couple of pages in length. They deal with topics as diverse as terrorism, intelligent design, music, Machiavelli, universities, paedophilia, mathematics, the origins of the state, Tony Blair, probability theory, Australian politics and avian flu. There are altogether 55 essays, some of them brilliant deconstructive analyses of the contradictions in contemporary politics, others remarkably sensitive re-readings of the classics, but some also lapse into the banal. Two brief illustrative excerpts: firstly from an essay on Bach (coming after previous disquisitions on atheism and intelligent design):

\section{https://repository.uwc.ac.za/}


The best proof we have that life is good, and therefore that there may perhaps be a God after all, who has our welfare at heart, is that to each of us, on the day we are born, comes the music of Johann Sebastian Bach. It comes as a gift, unearned, unmerited, for free.

How would I like to speak just once to that man, dead now for these many years! "See how we in the twenty-first century still play your music, how we revere and love it, how we are absorbed and moved and fortified and made joyful by it," I would say. "In the name of all mankind, please accept these words of tribute, inadequate though they are, and let all you endured in those bitter last years of yours, including the cruel surgical operations on your eyes, be forgotten." (2007:221)

Secondly, from an essay titled "On Fire and Water":

The more a fire devours, the bigger it gets; the bigger it gets, the more its appetite grows; the more its appetite grows, the more it devours. All that refuses to be devoured by fire is water. If water could burn, all of the world would have been consumed by fire long ago. (2007:215)

The above two excerpts indicate not only the fragmented and disparate subject matter of the novel, but also its unevenness, slipping from the sublime to the banal. Is Coetzee seriously asking his readers to consider the possibility of water burning? Or is this slippage into the commonplace a deliberate authorial strategy, a staged evidence of "late style"? One cannot be quite sure.

And who exactly is writing these essays? The author-figure in DBY is identified as John C, who, like J.M Coetzee, is a South African author, recently immigrated to Australia. Also, like John Coetzee, the supposedly fictive John C is the author of a novel titled Waiting for the Barbarians. And Coetzee has written on Bach admiringly before. In several other details, the biography of the actual author and his fictive doppelgänger cohere, making this novel yet another instance of a long line of fictional experiments beginning with Dusklands in which author, narrator and character slide into each other. But we cannot simply treat DBY as a form of staged autobiography, for Coetzee muddies the waters: his John C was born in 1934, and is thus a projected seven year older, a more markedly geriatric self. In other words, John C can be understood as a fictive late form of John Coetzee, embodying, as the novel shows, unresolved contradictions. He lives alone, is afflicted by failing health (possibly the onset of Parkinson's), and his smelly clothes and the cockroaches in the kitchen tell us that he has entered into an irrevocable decline. He no longer has the strength to write a novel, instead he speaks his mordant thoughts into a dictaphone: how taxes are a form of robbery, that Tony Blair is a "monkey", why universities are in terminal decline, if it matters that animals are slaughtered inhumanely, that classical music is no longer viable today, and so on. Death

$$
\text { https://repository.uwc.ac.za/ }
$$


and mortality proliferate in the text, not only in the autobiographical narrative, but also in the essays about animal slaughter, suicide bombers, the war on terror, ruminations on his dead father, guided missiles and on dead writers.

That Coetzee manages to extract a novel from such unpromising pedantic material is one of the pleasures of the book. This is achieved through the introduction of subplots in the form of second and third "diaries" in which the "Strong Opinions" are undermined, literally, from the textual space below. John C meets a sexually alluring young Filipina woman, Anya:

My first glimpse of her was in the laundry room. It was mid-morning on a quiet spring day and I was sitting, watching the washing go around, when this quite startling young woman walked in. Startling because the last thing I was expecting was such an apparition; also because the tomato-red shift she wore was so startling in its brevity. (2007:3)

The Hobbes-quoting philosophizing of the opening essay "On the Origins of the State" is strikingly contrasted with common garden-variety lechery, and in the course of the novel, we read how John $\mathrm{C}$ succeeds in persuading (seducing?) the beauteous Anya to type his essays - with entirely ulterior motives. Anya's background is not secretarial she has worked in "human resources" as receptionist in a euphemistically named "cat house", and in her typing she relies on the hit and miss vagaries of spell-check. This is of course Coetzee, a well-known perfectionist in matters of language, having bitter fun with himself: his aged alter ego's words are being mangled by a barely literate dilettante, a writer's ultimate torment that he is prepared to endure for the sake of the visual delights of Anya's delectable body. Not that this late love is ever consumed: John C speaks of his desire for her as a "metaphysical ache" (2007:7).

Part of the ingenuity here is the organization of text on the page: typographically, DBY is a split-screen novel in which two seemingly disconnected blocks of text vie for readerly attention: at the top of the page the intellectual essay, a line, and then the reflective thoughts of the author, about his writing, himself, but predominantly about Anya. We hear the confession - below the line, below the belt -- that he has not been honest to Anya: he does not really need a secretary at all, his German publisher is perfectly capable of transcribing dictaphone tapes. But Anya is not merely a naïve, empty-headed bimbo. Soon a third subscript layer is added: Anya's voice, and we see how she sees him, and through him. An elaborate game of mirrors evolves, in which Anya's perspective destabilizes the self-authored version of events:

As I pass him, carrying the laundry basket, I make sure I waggle my behind, my delicious behind, sheathed in tight denim. If I were a man I would not be able to keep

$$
\text { https://repository.uwc.ac.za/ }
$$


my eyes off me. ... And I turn my back and off I go with a waggle of the bum, his eyes avid upon me. (2007:25, 30)

In the first pages of the novel, the three layers are neatly stacked underneath each other as self-contained typographical units, but soon the personal narratives (John C's and Anya's) spill over the edge of the page and lead onwards, following onto the pages to come. Narrative and chronological order is disturbed; prolepsis and analepsis blur into each other. A form of contrapuntal reading (another Saidian term) is encouraged. White, empty space on the page is used effectively, for example when Anya temporarily leaves John $\mathrm{C}$ after an argument, and her absence leaves him poignantly silent. The reader is continually forced to decide between a vertical and horizontal reading, flipping pages backwards and forwards: a disturbing and unsettling hypertextual experience that exploits the tension between different narrative strands. For example: Anya has her own opinions on the essays. The steady diet of philosophical abstractions and cynical political argument that she has to type leaves her cold: "Write about cricket", she says, "Write about the world around you. Write about the birds. There are always a mob of magpies strutting around the park as if they own it" (2007:35), thus becoming a reader. Later, we see that John C has indeed followed her advice and has started to pen a series of gentler opinions, including pieces on cricket and magpies. Even he recognizes that his own fossilised views are out of step with the modern world: "there are flickering moments when I can see these hard opinions of mine through her eyes - see how alien and antiquated they may seem ... like the bones of some odd extinct creature, half bird, half reptile, on the point of turning into stone" (2007:136-7).

As the relationship evolves from the initial game of mutual dissimulation to eventual truth-telling, the secretary has transformed herself into a "secret aria", a muse of the unlikeliest kind. And John C asks himself: "is she the one who has been assigned to conduct me to my death? If that is so, how odd a messenger, and how unsuitable" (2007:60-1), comparing his fate to that of the apocryphal brothel client who has his heart attack in media res: embarrassing for an old man and a famous author to sink so low. Implicit then in the relationship is the idea of shame and dishonour. John C learns to see himself through others, principally through Anya, as a lecherous "crumpled old man". Forced to admit that his intentions were dishonourable, Anya tells him a story: how she was repeatedly raped by three American college boys on their yacht in the Caribbean. Her rape has not dishonoured her, she claims, but the perpetrators: "The dishonour sticks to the man, not the woman" (2007:102). But John disagrees:

No man is an island ... We are all part of the main... Dishonour won't be washed away. Still has its old power to stick. Your three American boys - I have never laid eyes on them, but they dishonour me nevertheless. And I would be very surprised if in your innermost depths they did not continue to dishonour you. (2007:106-111)

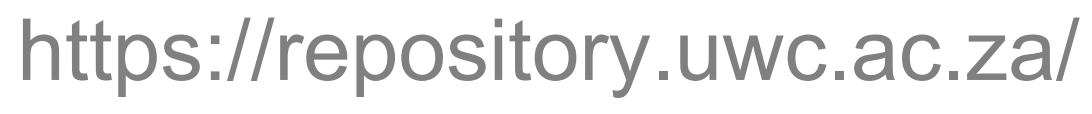


The idea that he should feel shamed and dishonoured by the actions of young American men, half a world away, is a curious one, born of a shared guilt. If one man rapes a woman, are all other men implicated, their honour called into question? It is this idea of an indivisible humanity ("No man is an island ... We are all part of the main") that DBY explores not only in relationship to the personal and private, but also in respect to the public or political. "When you live in shameful times," Coetzee's narrator says, "shame descends upon you, shame descends on everyone" (2007:96).

The novel's ethical philosophy that revolves around uneasy questions about shame and dishonour (or "Disgrace effects" to use the title of a paper by Peter McDonald), however soon verges from the nuances of the interpersonal into a more radical, even extremist form of public position-taking that is calculated to provoke and offend. How else are we to interpret John C's contrarian political views that not only endorse a sympathetic understanding of Islamist suicide bombers and align the murderous excesses of Nazi Germany with the US government (in DBY), but even more generally, associate the horrors of the death camps with the everyday, normalised practice of eating meat (in Elisabeth Costello)? But here, in DBY, Coetzee has a particular target in mind: the USA. Just as the American college boys in the Caribbean who assume that they can rape with impunity, America as a country has committed criminal acts of torture and war in the name of democracy and liberty, that bring profound dishonour to its citizens -- and to everyone in the world. This shame is so great, that his narrator would not be surprised "if today I heard that some American had committed suicide rather than live in disgrace" (2007:43). Rather than live with the shame of being an American, it is suggested implausibly, one possible moral choice would be "honour suicide" (2007:40). Post 9/11 America under Bush, Cheney and Rumsfeld does not only commit disgraceful acts on foreign soil (Guantanamo Bay, also located in the Caribbean) but is characterised domestically by an extreme "climate of whipped up fear" that has made democratic dissent near unfeasible, and Coetzee's narrator asks:

Impossible to believe that no one has yet plotted to assassinate these criminals in high office. Has there perhaps already been a Stauffenberg plot, record of which will at some time in the future emerge into the light of day? (2007:41)

The implied association of America with the Nazi Germany is an extreme and provocative one, but there are other even more disturbing analogies, if we read these views in conjunction with his essays on $\mathrm{Al}$ Quaida and Terrorism. Is there really that much difference, Coetzee's novel asks, between the American citizen who commits an honourable suicide rather than live with the burden of dishonour, and the Palestinian suicide bomber who, in the face of a powerful enemy, has no other way to "save [his] honour except by desperately and extravagantly throwing away [his] life" (2007:30).

\section{https://repository.uwc.ac.za/}


Coetzee's position, penned long before the Obama inauguration changed the national and global mood, is an extreme indictment of what America stands or stood for. But before we can comfortably dismiss DBY as a historical period piece, associated with the Bush presidency, whose political misdemeanours can now be brushed aside, Coetzee has another essay up his sleeve. It is about the curse, arguing, Biblically, that the sins of the fathers will be visited on their sons:

There must be people all over today's world who, refusing to accept that there is no justice in the universe, invoke the help of their gods against America, an America that has proclaimed itself beyond the reach of the law of nations. Even gods do not respond today or tomorrow, the petitioners tell themselves, they may be stirred to action a generation or two down the line. (2007:48)

Like young Germans or young white South Africans who proclaim that they are not murderers, fascists or racists, it is not easy to shrug off the past, there is the curse of their parents or grandparents on them, continuing to dishonour their present lives. Coetzee's politics, reflected through his fictional late alter ego, are radically antiredemptive and resistant to historical closure, instead offering a bleak future haunted by its traumatic past from which there is no possibility of escape. The "Strong Opinions" of DBY that mark Coetzee's brash venture into post 9/11 global politics are thus a form of late style in which he is uncompromising, provocative and impolite.

In the final section of this article I would like to return to the aesthetic or stylistic markers of late style by comparing the language of DBY to that of Coetzee's earlier fiction. As we will recall, Coetzee claims of aging writers that the "texture of their prose becomes thinner, their treatment of character and action more schematic" (2007:193). This diagnosis of aesthetic curtailment appears to be borne out by a comparison of his own earlier and late work. Choosing appropriate passages from Coetzee's large corpus of fictional work is of course a matter of considerable arbitrariness, but in this case the randomness has been somewhat limited by choosing comparable extracts in which the novels' main male protagonists come face to face for the first time with a female character who is the object of their love interest. Apart from DBY, this plot configuration exists in a number of Coetzee's novels, the earliest being waiting for the Barbarians (1980). In DBY, as cited earlier, the initial meeting of the male protagonist and his female love interest is described as follows:

My first glimpse of her was in the laundry room. It was mid-morning on a quiet spring day and I was sitting, watching the washing go around, when this quite startling young woman walked in. Startling because the last thing I was expecting was such an apparition; also because the tomato-red shift she wore was so startling in its brevity. (2007:3)

\section{https://repository.uwc.ac.za/}


The initial description is clearly singularly focused on the shortness of the "tomato-red shift", but what is striking here is the disassociation between the "brevity" of the descriptive language of this prose extract, and the erotic plenitude of the visual details of the scene, which we must assume are being absorbed intently by the gaze of the focaliser. The primary object of the narrator's visual attention here - the long, exposed legs - is noticeably absent in the description itself. In the ensuing description, we hear that she "has black black hair, shapely bones" and "a certain glow to her skin, lambent might be the word" (2007:6). But the half-ventured excursion into more detailed, nuanced description ("lambent might be the word") soon returns to the "bright red shift" and then, presumably after the eye has wordlessly traversed the full expanse of the exposed leg, to the similarly crassly coloured "thongs". The erotic subtext of sexual longing is further evident in the suggestive closing aside: "Thongs of the kind that go on the feet" (2007: 6). The logic of Coetzee's descriptive system, that that which really matters is that which is not described, is thus fittingly encapsulated in the object itself: the briefness of the "tomato-red shift" becomes a figure for the "brevity" of the descriptive prose. What Anja really looks like remains elusive; and the term Coetzee uses to represent her, "an apparition", is an apt sign of the lack of descriptive detail.

A comparison to a structurally similar plot moment in Disgrace may reveal both similarities and differences. It is a description of the first encounter between the protagonist David Lurie and Melanie Isaacs:

She is dawdling; he soon catches up with her. 'Hello', he says.

She smiles back, bobbing her head, her smile sly rather than shy. She is small and thin, with close-cropped black hair, wide almost Chinese cheekbones, large, dark eyes. Her outfits are always striking. Today she wears a maroon miniskirt with a mustardcoloured sweater and black tights; the gold baubles on her belt match the gold balls of her earrings. (1999: 11)

Both Anja and Melanie are attractive black-haired women wearing gaudy miniskirts, coloured red in DBY, and maroon in Disgrace. But apart from this parallelism, the two descriptions of female presence are markedly different. The descriptive details in the above passage clearly show how DBY, by contrast, eschews all conventional narrative language with which a character can be "known", which is primarily a detailed description of facial expression. We learn here not only that Melanie smiles, but are given a nuanced interpretation of the quality and meaning of the smile which is not "shy" but "sly". Lurie's subtle, detailed reading of Melanie's smile (and metonymically of her character) is of course, as we get to understand later, fundamentally mistaken, and is coloured by his predatory desire rather than by real insight.

\section{https://repository.uwc.ac.za/}


The larger point though is that in Coetzee's narratives detailed description of a character's facial features and expression is intimately keyed with knowledge, even if this knowledge is flawed as in the example above. Another much earlier example is the encounter between the magistrate and the barbarian girl in Waiting for the Barbarians: A few days later I see her crossing the square, walking slowly and awkwardly with two sticks, the sheepskin coat trailing behind her in the dust. I give orders; she is brought to my rooms, where she stands before me propped on her sticks. 'Take off your cap,' I say. The soldier who has brought her in lifts off the cap. It is the same girl, the same black hair cut in a fringe across the forehead, the same broad mouth, the black eyes that look through and past me. (1980: 26)

Earlier, the magistrate had seen her in the square, and he notices that she "has straight black eyebrows" and "the glossy black hair of the barbarians" (1980: 25). Again, as in the extract discussed above, a detailed description of facial particulars is foregrounded in the narrative, together with other details concerning dress. Indeed, it is the girl's damaged body (her feet and her eyes) that becomes an obsessive focus for the magistrate.

In all of Coetzee's pre-millenial fictive writing a similar analysis could be made, showing a richness of description and a full-texturedness of characterisation that is curiously absent in DBY. The late novel's stylistic simplification or sketchiness in descriptive language is however not necessarily a marker of literary deficiency. Coetzee can get away with saying so much less, if we look at the rich implicature of the prose. Coetzee's late style then, as evident in DBY, manifests itself as a descriptive sparseness in which the figure of the desired female character is almost completely reduced to its sexualised essentials.

To conclude then, Coetzee's post-Nobel late style may be understood as a form of literary licence to dispense with the conventions of more complex character narration and plot development, as well as a freedom to give offence. As Said puts it about the late style of aging artists:

It is as if having achieved age, they want none of its supposed serenity or maturity, or any of its amiability or official ingratiation. Yet in none of them is mortality denied or evaded, but keeps coming back as the theme of death which undermines, and strangely elevates their uses of language and the aesthetic. (2006:143)

Instead of serene contemplation from the Olympian vantage point of literary fame, Coetzee through his narrative stagings, continues to quarrel the world, in a more intense and direct form, than in earlier allegorical novels such as Waiting for the Barbarians. Faced with death there is a process of remorselessly candid self-revelation, finally seeing himself through his imagined father's eyes as a "selfish child ... who has turned in to a

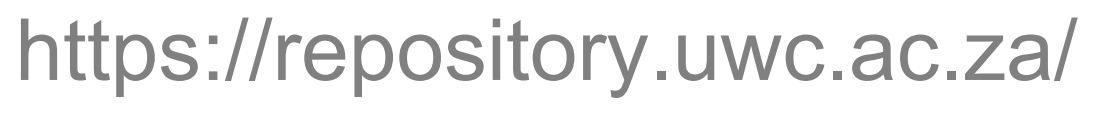


cold man; how can I deny it?” (2007:166). As Anya discovers, besides the classics of Tolstoy and Dostoevsky the bookshelf also contains less salubrious titles such as "Russian Dolls XXX". Even late desire becomes transformed into dishonour. Despite or perhaps because of such truths, a kind of redemption is finally possible. Finally she is given the voice, his subjectivity fading into the background. In its complex meditations on desire, death and disgrace, DBY is thus a problematic late form of fictive autobiography, in which Coetzee deconstructs his celebrated, Nobel Prize winning public literary persona. 
Works Cited

Attwell, D. 2002. 'Race in Disgrace', Interventions 4/3: 374-83.

Coetzee, J.M. 1980. Waiting for the Barbarians. Harmondsworth: Penguin.

Coetzee, J.M. 1999. Disgrace. London: Secker \& Warburg.

Coetzee, J.M. 2005. Slow Man. London: Secker \& Warburg.

Coetzee, J.M. 2003. Elisabeth Costello: Eight Lessons. London: Secker \& Warburg.

Coetzee, J.M. 2007. Diary of a Bad Year. London: Harvill Secker.

Lenta, M. 2007. Review of Nadine Gordimer Beethoven Was One-Sixteenth Black and Other Stories. Available: http://www.literarytourism.co.za

Gordimer, N. 2007. Beethoven Was One-Sixteenth Black and other Stories. Harmondsworth: Penguin.

McDonald, P.D. 2002. “Disgrace Effects.” Interventions 4.3: 321-330

Marcus, D. 2009. “The Ambivalence Artist”. Dissent 56/1:115-119.

Mars-Jones, A. 2007. “Even Nobel winners can make mistakes”. Review of J.M Coetzee Diary of a Bad Year. In The Observer, 26 August. Available: www.guardian.co.uk/books/jmcoetzee

Said, E. 2006. On Late Style: Music and Literature Against the Grain. New York: Knopf. 